\title{
The Impact of Dividend Policy on Stock Price: A Study of Fuel, Power and Cement Industry in Bangladesh
}

\author{
Md. Bellal Hossain Raju ${ }^{1}$, A. H. M. Asaduzzaman ${ }^{2}$ \\ ${ }^{I}$ MBA Program, Department of Finance, Faculty of Business Studies, University of Dhaka, Dhaka, Bangladesh \\ ${ }^{2}$ Back Office Division, BASIC Bank Limited, Head Office, Dhaka, Bangladesh
}

\begin{abstract}
Commercial organizations in Bangladesh are experiencing rivalry among themselves because of economic struggle globally and attempting to remain competitive in these changeable economic surroundings. This paper intends to analyze the impact of dividend policy on the market price of stock in Bangladesh. The numbers of statistic community are 330 companies in Dhaka Stock Exchange. All 24 companies belong to Fuel, Power and Cement industry listed at DSEX index are included as the sample for a phase from 2000 to 2016. In this paper, Fixed Effect Model along with Random Effect Model have been used to estimate outcomes. Both Models are exercised on panel data for explaining the association between dividend payments and share prices after adjusting several variables including Earnings per Share, logarithm value of Profit after Tax, Growth of Asset and Dividend Payout Ratio. The study also checked both the Models and found Random Effect Model is more significant than Fixed Effect Model. Afterward, this paper applied the multicollinearity test to determine is there any correlation among the variables and found no multicollinearity. This paper found a weak form market exists in Bangladesh and investors choose stock dividend more than the cash dividend.
\end{abstract}

Keywords: Cash or Stock Dividend, Dividend Policy, Dhaka Stock Exchange, Fixed and Random Effect Model, Stock Price

\section{Introduction}

There are many broad research areas in finance. Among the areas, an important one is dividend policy, but the argument either dividend policy modifies stock prices or not remains questionable among administrators, decision makers, and scholars for several years. The presence of dividend policy carries significance for financiers, administrators, bestowers and another one with a vested interest. Investors give supreme importance to dividend policy. They recognize dividends as the primary income source. Most importantly, they use dividend policy as a means of evaluating company from the investor's perspective. Through the use of dividend policy, a company can be valued to get the productive capacity of the business in the cash form or not. Choosing a proper dividend policy always requires a critical arrangement for a company. It is because the volume of dividends paid or will pay to the stockholders determines the adaptability to spend on projects that will take place in future. When any organization gives more dividends then, fewer funds will be free to invest in the forthcoming projects. Creditors like bond holders, debenture holders, are also concerned about the Return on Investment of the company. If the company paid an excess Return on Equity then within a short time, it will fall on difficulties for managing operating and other expenses of the organization and also for the repayment of their debts.

The primary goal of the shareholder aims to the maximization of profit. A company's dividend policy influences the decisions of that company's investors toward earnings from the investment. Maximizing profit of shareholders is the main intent focused on the dividend policy. Arnold [1] revealed that statement and also included this intent is achieved the highest outcome through increasing shareholders purchasing power. Therefore, boosting of shareholders' return largely rely upon the dividend decision or policy. It is because this wealth would shape the purchasing ultimately consumption orders of shareholders. To the shareholders, the dividend payment is one of the significant elements of stock returns. It could present a sign to the investors that the firms are complying with good corporate governance practices or not. Besides, the shift of share price is the systemic risk faced by the investors who grasp ordinary shares investment. Investor's character is risk averse, and the instability of their investments is important to them because it is a way of determining the level of risk exposed to them. The factors, which motivated this study is to obtain the influence of dividend policy on the stock price.

The aspiration of the study is to determine the influence of dividend policy on the share prices of Fuel, Power and Cement sector in Bangladesh during 2000 to 2016. It is not only a matter of great importance to the management that what is the effect of a firm's dividend policy on the current stock price but also to the investors and economist. Investors plan to make their portfolio by considering the dividend policy and economists seek to understand and make valuation the functioning of the capital market. This importance make questions, how much impact causes due to dividend policy on firm's value and subsequently on the price of the stock? Which 
factor influence the share price of the company? Is there any impression of Earnings per Share, Return on Equity or Growth of Asset on the stock prices in the Dhaka Stock Exchange?

\section{Literature Review}

Among the crucial areas in Finance, dividend policy is one of them. Previously, several researchers have carried studies over this area, which explains the association between dividend arrangement and share prices. Novel researchers can take benefits and insights from them to scrutinize the dividend policy to work further in their way. When someone talks about the dividend policy, the name of Lintner comes first. Lintner [2] appealed with the question having a great interest until now. His inquiry is that "what decisions are taken by managers that influence the extent, form, and scheduling of payments of dividends?". Later Modigliani and Miller [3] presented a theory about dividend policy. Their concept is popularly known as the theory of Dividend Irrelevance, which explains share prices are not influenced by the dividend policy. Several studies conducted by Black and Scholes [4], Chen, Firth and Gao [5], Adefila, Oladipo and Adeoti [6], Uddin and Chowdhury [7], Denis and Osobov [8], and Adesola and Okwong [9] presented substantial proof in backing the Dividend Irrelevance Approach and did not acknowledge it germane to share prices in the capital market.

Gordon [10] introduced the theory of Dividend Relevance representing the another sight of the dividend policy. Gordon firmly believed that the market value of stocks and the worth of the company are affected by the dividend policy. Dividend income is always considered secured by investors than capital gains. Dividend Relevance Argument was supported by researchers like Travlos, Trigeorgis and Vafeas [11], Baker, Powell, and Veit [12], Myers and Frank [13], Dong, Robinson and Veld [14], and Maditinos, Sevic, Theriou and Tsinani [15]. No relationship was attained between the dividend decision and share prices by Black and Scholes [4]. The results of the researchers as mentioned above described that the dividend policy has no effect on stock prices, and it mostly relies on the shareholder's choice.

Barclay and Smith [16] published a paper about the maturity of business debt structure and stated that low growth firms have higher dividend payout ratio and level of debt than the high growth firms. As a result, high dividend payout is got the priority of investors, and they regard capital gains riskier than dividend payout. Rachim and Allen [17] has found out no association with the yield of dividends and share market prices. They have been tested 173 listed firms in Australia and found a positive correlation between the market price of stock and size of the firm with Earnings per Share and debt leverage and a negative correlation between share market prices and Dividend Payout Ratio. Besides, Baskin [18] examined 2344 listed firms in USA market from the phase of 20 years. In his examination, he got share price and dividend yield has a substantial negative correlation.

Ho [19] performed a study using panel data method and fixed effect model, which is pertinent to the dividend policy. In his study, he detected a positive correlation between the volume of Australian listed companies and the dividend policy; he also found a similar relation to the dividend policy with Japanese companies' liquidity. Besides, a negative relation was found between the risk of Japanese organizations and the dividend policy. Pradhan [20] explicated the influence of retained earnings and dividends payout on the stock prices in Nepal Stock Exchange Limited. The findings of his work showed dividend payout has a strong correlation with the price of the share. His study also stated that stock price has very feeble relation with retained earnings. His study further described that Nepalese investors prefer dividends earning rather than capital gain. Nishat and Irfan [21] conducted a study of 160 firms enlisted in the Stock Exchange of Pakistan covering from 1981 to 2000. Regression analysis among exploded views had been used in their study and found the stock market price is positively involved with dividend income and dividend payout ratio.

Adeoti, Oladipo, and Adefila [6] analyzed some Nigerian companies to have influential factors on the dividend decision and policy. Their analysis found Nigerian companies choose continuous dividend payments to resemble expectations of stockholders. Their study did not find any significant involvement among dividend payouts, comprehensive income and market prices of stock. By examining data on 483 companies from Multex Investor Databank, Myers and Frank [13] revealed a significant correlation between Dividend Payout Ratio and Price Earnings Ratio. Additionally, their study found a vital positive relationship between dividend payments and Debt Equity Ratio. The managers in Norway are shaping dividend policy by using survey method. The outcomes of a survey explored that present and future income, sustainable income, the extent of financial debt and leverage and firm's liquid ability are key factors considered by managers while creating policies regarding firm's dividend [22].

A study on the Ghana Stock Exchange carried by Amidu [23] showed the impact of the dividend payments on the achievement of the firms. In his study, a positive association was found between dividend policy, earnings from assets and sales growth while a negative relationship was found between earnings from assets, leverage, and Dividend Payout Ratio. For the period from 1988 to 2004 one more study performed by Hedensted and Raballe [24] in Denmark. Their study recognized a positive correlation between net income of the firms and Cash Dividends, non-distributed earnings, Return on Equity and dimension of the firm but 
unsuccessful to define any association between the factors like dividend policy and Debt to Equity Ratio. Adesola and Okwong [9] obtained a result about the aspects influencing the divided policies based on the practical data of Nigerian firms. They found dividend decision is considerably linked with firm's income, Earnings per Share, and last year dividends. Their result also explained dividend policy is not impacted by company's size and growth.

Another study performed to find out the effect of policy associated with dividend on the price of the share by Hussainey, Mgbame and Chijoke-Mgbame [26]. The findings of their paper explored that share price movements have an active link with dividend income and a negative link with Dividend Payout Ratio. Their study also explored that share price movement in the United Kingdom are caused by companies' income, the rate of growth, firm's overall and debt size. Powell and Baker [27] acquired the views of managers of Indonesia about the determinants affecting on dividend decisions, issuances of dividend and clarification for dividend payments. The findings of their analysis revealed that managers of Indonesian firm's focus on the steadiness of income and the amount of prevailing and anticipated net revenues act as crucial factors affecting dividend policy. Their study also conveyed that dividend decision has substantial impacts on company's value and managers use several dividend approaches including life cycle models, catering and signaling while creating their dividend decisions.

In Bangladesh, Al-Hasan, Asaduzzaman and Karim [28] performed a study of 28 companies from automobile, cement, textile and pharmacy industry listed in DSE. They found a significant association between the market price per share and dividend per share. Their analysis also showed that dividend policy has a substantial impact on the market price per share. Another study conducted by Mamun, Haque and Ahshanul [29] found that dividend disbursement convey a message to the market, which could adjust share price but market failed to adjust accordingly in a balanced way for the firms they studied. The results they found are similar to the results found in an earlier study on the capital market of Bangladesh conducted by Uddin and Chowdhury [7].

\section{Data Collection Technique}

\section{Methodology of the Study}

All 24 listed firms from the Fuel, Power and Cement industry in the Dhaka Stock Exchange Limited (DSE) are taken as the sample for 17 years from 2000 to 2016. There are 7 companies in Cement industry and 18 firms in Fuel \& Power industry listed in the DSE. The required data are primarily compiled from the following sources:

- Audited Financial Statements of the companies, which contain types of firms' activities in complete form, asset size, the number of shareholders, and Profit after Taxes.

- The entire stock price index in DSE and daily closing stock prices were collected from the DSE data archive.

- LankaBangla Financial Portal for collecting dividend history.

\section{Definition of Variables}

Stock Price Volatility (SPV) is used as a dependent variable in this paper. To measure the SPV, annual maximum and minimum share prices of the respective year are used by following method developed by Parkinson [30]. The given formula is used to obtain the SPV.

$$
\left(\mathrm{H}_{\mathrm{it}}-\mathrm{L}_{\mathrm{it}}\right) \div\left(\left(\mathrm{H}_{\mathrm{it}}+\mathrm{L}_{\mathrm{it}}\right) \div 2\right)
$$

In this formula (i), $\mathrm{H}_{\mathrm{it}}$ represents the highest stock price of the firm ' $\mathrm{i}$ ' in the year ' $\mathrm{t}$ ' and $\mathrm{L}_{\mathrm{it}}$ denotes lowest stock price of the firm ' $i$ ' in the year ' $t$ '.

Cash Dividend (CD) is the primary type of dividend payment. CD has the direct link with stock prices either positive or negative. Mogere [31] found a weak, insignificant relationship between CD and stock prices. One of the important types of the dividend is Stock Dividend (SD). The views of the shareholders can be seen when SD declared, and it can be reflected in the share price. It has an influence on stock price and may show a positive or negative reflection. Horne, Wachowicz and Kuhlemeyer [32] described the impact of SD by getting a negative relationship between the number of shares and share prices and EPS without affecting the firm's value. Travlos, Trigeorgis and Vafeas [11], Akbar \& Baig [25], Khan, Aamir, Qayyum, Nasir and Khan [33] got a significant and positive link between SD and share prices.

Another important variable, Profit after Tax may also be known as net income is used in this paper. It has a positive and meaningful relationship with stock price. Later, the association is supported by Adesola and Okwong [9], Khan, Aamir, Qayyum, Nasir and Khan [33], Pani [34], and Ahmed and Javid [35]. To get the value of EPS elaborately Earnings per Share, at first preferred stock is subtracted from the net income. Afterward, the outcome is divided by the total number of shares outstanding. It is a parameter for identifying the profitableness of a corporation. Many researchers used EPS as a control variable like Adesola and Okwong [9], Allen and Rachim [17], Baskin [18], Liu and Hu [36], and Chen, Huang and Cheng [37]. They concluded that 
EPS has a positive and significant correlation with the stock price. On the other hand, Adefila, Oladipo and Adeoti [6] did not get any significant association between EPS and stock price.

Return on Equity (ROE) is used as an important variable in this paper. For the calculation purpose of ROE, the amount of Profit after Tax is divided by the shareholders' common equity. According to previous studies conducted by Raballe and Hedensted [24], Khan, Aamir, Qayyum, Nasir and Khan [33], Liu and Hu [36], and Ling, Mutalip, Shahrin and Othman [38] and there has a positive association between ROE and stock price.

The Growth of Asset (GA) is used in this study as a key control variable. The formula to get GA variable is as under,

$$
\mathrm{GA}=\Delta \text { Asset }_{\text {it }} \div \text { Asset }_{\text {it- } 1}
$$

In this formula (iii), $\Delta$ Asset $_{i t}$ indicates a change of total assets for the firm ' $i$ ' in the current year of ' $t$ ' than the previous year of ' $t-1$ ' and Asseti $i_{t-1}$ denotes total assets of the firm ' $i$ ' in the year ' $t-1$ '.

In this study, Dividend Payout Ratio (DPR) is used as one of the important independent factors by considering a proxy variable of dividend policy. The amount of cash dividend per share is divided by the net income (after tax) available for each shareholder for calculating DPR. The formula is as under,

$$
\mathrm{DPR}=\mathrm{DPS}_{\mathrm{it}} \div \mathrm{EPS}_{\mathrm{it}}
$$

In this formula (ii), DPS ${ }_{\text {it }}$ indicates dividend per share of the firm ' $i$ ' in the year ' $t$ ' and $\mathrm{EPS}_{\mathrm{it}}$ denotes earnings per share of the firm ' $i$ ' in the year ' $t$ '.

\section{Specification of Model}

This study used panel data method to identify the relationship between the stock prices and dividend policy. Fixed Effect Model together with Random Effect Model regressions are used to analyze panel data. In the study, Fixed Effect Model is employed for controlling the stable features of the firms for a static period. This method is famous for eradicating the biasedness of data and eventually gives good outcomes statistically. This model also works better when variations exist within samples. When the features of the sample vary, Random Effect Model is used. The appeal of firms i.e. volume, capital size, the number of stockholders, category of business, and company's income are not similar for all enterprises. For that reason, this technique is fit to explicate the differentiation among the corporate bodies. Similar approaches are also applied in their researches by Ho [19], Hussainey, Mgbame and Chijoke-Mgbame [26], Khan, Aamir, Qayyum, Nasir and Khan [33], Rashid and Rahman [39], and Nazir, Nawaz, Anwar and Ahmed [40].

The intent of this paper is to reveal the impact between share prices and dividend policy after the adjustment of Earnings per Share, Dividend Payout Ratio as well as Growth of Asset. This study also attempted to identify the relation of other key variables such as Profit after Tax, Stock Dividend and Return on Equity. The augmentation of these variables will amplify stock prices of the Fuel, Power and Cement sector in Bangladesh. The understated equation of regression is applied in this paper.

$$
\mathrm{SPV}=\alpha_{0}+\alpha_{1} \mathrm{CD}_{\mathrm{i}}+\alpha_{2} \mathrm{SD}_{\mathrm{i}}+\alpha_{3} \ln \left(\mathrm{PAT}_{\mathrm{i}}\right)+\alpha_{4} \mathrm{EPS}_{\mathrm{i}}+\alpha_{5} \mathrm{ROE}_{\mathrm{i}}+\alpha_{6} \mathrm{GA}_{\mathrm{i}}+\alpha_{7} \mathrm{DPR}_{\mathrm{i}}
$$

\section{Data Processing and Analyzing Technique}

Stata 13 and Microsoft Excel are used to process and analyze the data. Dependent and independent variables are analyzed by using correlation as well as linear regression i.e. Fixed Effect Regression and Random Effect Regression. Then Hausman Test is performed for checking which model is effective. Regression analysis is mainly used to analyze the relationship of dividend policy and share price of the companies. Afterward, multicollinearity test is run to determine any correlation among the independent variables.

\section{Data Description}

Table 1 displays the value of mean, minimum, maximum and standard deviations of entire variables included in the descriptive statistics.

Table 1. Descriptive Statistics (Sample Size: 24 companies; Period: 2000-2016)

\begin{tabular}{lccccc}
\hline \multicolumn{1}{c}{ Variable } & Observations & Mean & Min & Max & Std. Dev. \\
\hline Stock Price Volatility (SPV) & 263 & 0.66 & 0.12 & 1.86 & 0.38 \\
Cash Dividend (CD) & 264 & 3.53 & 0.00 & 38.00 & 6.40 \\
Stock Dividend (SD) & 261 & 6.12 & 0.00 & 200.00 & 16.22 \\
ln(Profit After Tax) ln(PAT) & 225 & 5.33 & -0.55 & 9.24 & 2.19 \\
Earnings per Share (EPS) & 254 & 7.70 & -8.13 & 48.55 & 10.21 \\
Return on Equity (ROE) & 253 & 0.11 & -4.79 & 0.91 & 0.37 \\
Growth of Asset (GA) & 239 & 0.14 & 0.00 & 1.75 & 0.32 \\
Dividend Payout Ratio (DPR) & 253 & 0.37 & -16.67 & 5.26 & 1.23 \\
\hline
\end{tabular}


Earnings per Share has the maximum mean value graded at 7.70 while Stock Price Volatility has an average value of 0.66 . The minimum mean value stays at 0.11 , which belongs to Return on Equity. The value of standard deviation can show the divergence in datasets. The largest standard deviation value is 16.22 for Stock Dividend. It indicates a great change in the stock trading prices of Fuel, Power and Cement industry in Bangladesh is by cause of Stock Dividend. The lowest standard deviation value belongs to Growth of Asset with 0.32, which indicates Growth of Asset causes smallest change in the share market values of Fuel, Power and Cement industry in Bangladesh.

\section{Analysis and Findings}

Table 2 displays the relationship amongst the different descriptive variables and stock prices, which is the dependent variable. Pearson Correlation technique is employed for this mission, and these variables are examined at 1 percent, 5 percent, and 10 percent significance level.

Table 2. Correlations among the Variables

\begin{tabular}{|c|c|c|c|c|c|c|c|c|}
\hline Variable & SPV & CD & SD & $\ln ($ PAT $)$ & EPS & ROE & GA & DPR \\
\hline SPV & 1.000 & & & & & & & \\
\hline $\mathrm{CD}$ & $-0.183^{*}$ & 1.000 & & & & & & \\
\hline SD & $0.175 * *$ & -0.088 & 1.000 & & & & & \\
\hline $\ln (\mathrm{PAT})$ & 0.119 & $0.248^{*}$ & $0.138^{*}$ & 1.000 & & & & \\
\hline EPS & 0.089 & $0.724 * * *$ & $0.287^{*}$ & 0.328 & 1.000 & & & \\
\hline ROE & 0.024 & 0.235 & 0.137 & $0.439 * *$ & $0.471 * *$ & 1.0000 & & \\
\hline GA & 0.112 & -0.042 & 0.103 & 0.157 & 0.014 & 0.073 & 1.000 & \\
\hline DPR & -0.136 & 0.211 & $-0.225^{*}$ & -0.198 & -0.074 & -0.233 & -0.112 & 1.000 \\
\hline
\end{tabular}

Stock prices of Fuel, Power and Cement industry in Bangladesh have a substantial relationship with the Stock Dividend and positive relationship with ln value of Profit after Tax and Earning per Share. Stock prices also have similar link with Return on Equity and Growth of Asset. These relations are confident at 95 percent level and 90 percent level of confidence. There is a significant relationship between the Cash Dividend and ln value of Profit after Tax and Earning per Share at 1 percent and 10 percent significance level and a negative correlation with Stock Dividend and Growth of Asset. Logarithm value of Profit after Tax and Earnings per Share have significant positive relation with Stock Dividend while Dividend Payout Ratio has significant negative relation with Stock Dividend both at 10 percent degree of significance. Both logarithm value of Profit after Tax and Earnings per Share have a significant link with Return on Equity having 1 percent and 5 percent significance level, and negative link with Dividend Payout Ratio. The Growth of Asset and Dividend Payout Ratio have an insignificant negative relationship.

Table 3 spectacles the outcomes of Multicollinearity Test to identify are there any correlations among the independent variables used in this paper. This study ran the Multicollinearity Test by using Variance Inflation Factors (VIF) method. As multicollinearity can deform the standard error of estimation and may, therefore, a guide to the erroneous conclusion, it leads to the necessity of checking the model used in this study. In the test, a mean VIF value of less than 10 is found, which is the sign of no multicollinearity in the model, and there is no correlation between the variables used in this paper.

Table 3. The Result of Multicollinearity Test

\begin{tabular}{|c|c|c|}
\hline Variable & VIF & 1/VIF \\
\hline Cash Dividend (CD) & 3.07 & 0.326044 \\
\hline Stock Dividend (SD) & 1.4 & 0.716449 \\
\hline $\ln$ (Profit After Tax) $\ln$ (PAT) & 1.35 & 0.743203 \\
\hline Earnings per Share (EPS) & 3.6 & 0.277904 \\
\hline Return on Equity (ROE) & 1.55 & 0.645165 \\
\hline Growth of Asset (GA) & 1.04 & 0.959968 \\
\hline Dividend Payout Ratio (DPR) & 1.25 & 0.799744 \\
\hline Mean VIF & 1.89 & \\
\hline
\end{tabular}

Table 4 displays the outcomes of Fixed Effect Model and the outputs of Random Effect Model are shown in Table 5. The outcomes of Random Effect Method justify the outputs presented in Table 2. Additionally, these outcomes explicate the importance of every single factor of dividend decision and policy included within the model as well as the importance carried by the model as a whole. 
Table 4. The Result of Fixed Effect Model

\begin{tabular}{lccc}
\hline \multicolumn{1}{c}{ Variables } & Coefficient & Standard Error & t-Statistic \\
\hline Constant & 0.7911 & 0.1019609 & 7.76 \\
Cash Dividend (CD) & -0.0039 & 0.0067701 & -0.57 \\
Stock Dividend (SD) & 0.0039 & 0.0017321 & 2.25 \\
ln(Profit After Tax) ln(PAT) & -0.0319 & 0.0176182 & -1.81 \\
Earnings per Share (EPS) & -0.0011 & 0.0051099 & -0.22 \\
Return on Equity (ROE) & 0.2709 & 0.2705592 & 1 \\
Growth of Asset (GA) & 0.1453 & 0.0916332 & 1.59 \\
Dividend Payout Ratio (DPR) & -0.0547 & 0.0472775 & -1.16 \\
\hline
\end{tabular}

Equation under Fixed Effect Model:

$\mathrm{SPV}=0.7911-0.0039 \mathrm{CD}+0.0039 \mathrm{SD}-0.0319 \ln (\mathrm{PAT})-0.0011 \mathrm{EPS}+0.2709 \mathrm{ROE}+0.1453 \mathrm{GA}-0.0547 \mathrm{DPR}$

According to the outcomes of Fixed Effect Model Stock Dividend, Return on Equity, and Growth of Asset has a significant positive association with share prices while logarithm value of Profit after Tax, Dividend Payout Ratio, and Cash Dividend have a negative relationship to market prices of share in this model. Random Effect Model found Stock Dividend, In(Profit after Tax), Earnings per Share, Return on Equity, and Growth of Asset has a significant positive relationship with share prices. Besides Cash Dividend along with Dividend Payout Ratio have a negative correlation to market prices of share in this model.

Table 5. The Result of Random Effect Model

\begin{tabular}{lccc}
\hline \multicolumn{1}{c}{ Variables } & Coefficient & Standard Error & t-Statistic \\
\hline Constant & 0.5524 & 0.1937 & 2.85 \\
Cash Dividend (CD) & -0.0065 & 0.0075 & -0.87 \\
Stock Dividend (SD) & 0.0035 & 0.0018 & 1.94 \\
ln(Profit After Tax) ln(PAT) & 0.0083 & 0.0385 & 1.22 \\
Earnings per Share (EPS) & 0.0045 & 0.0063 & 1.71 \\
Return on Equity (ROE) & 0.1028 & 0.3362 & 0.31 \\
Growth of Asset (GA) & 0.1950 & 0.1024 & 1.9 \\
Dividend Payout Ratio (DPR) & -0.0414 & 0.0496 & -1.16 \\
Prob > F = 0.0351 & & & \\
\hline
\end{tabular}

Equation under Random Effect Model:

$\mathrm{SPV}=0.5524-0.0065 \mathrm{CD}+0.0035 \mathrm{SD}+0.0083 \ln (\mathrm{PAT})+0.0045 \mathrm{EPS}+0.1028 \mathrm{ROE}+0.1950 \mathrm{GA}-0.0414 \mathrm{DPR}$

These results ensure that investors gave preference to the Stock Dividend for these three sectors from 2000 to 2016 time frame. Investors mostly show their interest in Stock Dividend for the cause of this type of dividend simply increases their quantity of shares, which leads them accomplished to obtain more dividends in future from these shares.

Table 6 presents the output of Hausman Test to resolve which model is more acceptable than the other. In this test, the null hypothesis was Fixed Effect Model is significant and alternative hypothesis was Random Effect Model is significant. Here, the output has the value of chi-square is 0.6262 , which is more than 0.05 meaning that alternative hypothesis cannot be rejected and should be accepted.

Table 6. The Result of Hausman Test

\begin{tabular}{|c|c|}
\hline Null Hypothesis & Fixed Effect Model is significant \\
\hline Alternative Hypothesis & Random Effect Model is significant \\
\hline \multicolumn{2}{|c|}{ Test: Ho: dissimilarity in coefficients is not systematic } \\
\hline $\operatorname{chi} 2(7)=$ & $(b-B)^{\prime}\left[\left(V \_b-V \_B\right)^{\wedge}(-1)\right](b-B)$ \\
\hline$=$ & 5.28 \\
\hline Prob $>$ chi2 & 0.6262 \\
\hline
\end{tabular}

Here, it was found that Random Effect Model is more significant than Fixed Effect Model to describe the relation among the variables used in this study. Random Effect Model is appropriate for this study, and Housman Test reflects the above statement. Results of Random Effect Model represents Stock Dividend, $\ln$ (Profit after Tax), Growth of Asset, Earnings per Share and Dividend Payout Ratio has a significance affiliation with share prices. Among them, Stock Dividend, Growth of Asset, $\ln$ (Profit after Tax), and Earnings per Share have a significant positive link with the share price and Cash Dividend and Dividend Payout Ratio have a negative link with the share prices of Fuel, Power, and Cement sector in the capital market of Bangladesh. It is noticeable that Cash Dividend and Return on Equity have a little insignificant relationship with share prices, which indicates the existence of the weak form market and the behavioral problem of investors in the market studied by this paper. 
Return of Equity has no significant relationship with the market price of the share. From the Random Effect Approach, it is one of the important things that share price has a positive consequence with Return on Equity in this study. This positive association proved that the management of organizations is using the shareholders' funds efficiently. An assertive link between Return on Equity and share prices is also identified by several researchers including Raballe and Heidenstam [24], Liu and Hu [36], and Ling, Mutalip, Shahrin and Othman [38].

\section{Conclusion}

The principal purpose of this study aims to detect the relation of dividend policy and stock market price. The listed companies of Fuel, Power and Cement industry in Bangladesh were taken in this study. Which type of dividend shareholders prefer: Cash or Stock? For this intention, 24 companies listed on the Dhaka Stock Exchange are picked from the phase of 2000 to 2016. The empirical evidence based on the Random Effect Model shows that there is a significant relation among Stock Dividend, Return on Equity, Growth of Asset, $\ln$ (Profit after Tax), and Earnings per Share. Besides, Cash Dividend and Dividend Payout Ratio show the negative involvement with the share prices in Bangladeshi Fuel, Power, and Cement sector. This study also found results that in the Bangladeshi capital market shareholders desire mostly in the stock dividend.

The value of $F$ statistics shows that the models are well fitted as well as whole variables used in this approach is significantly describing the movement in the share prices. The probability value of 0.0351 confirms that the entire model is properly fit with the data and the entire variable included in this model are significantly described the variation of the share market price.

Hence, it is proposed and recommended that this paper will assist the prospective researchers to examine other industries in Bangladesh with a variety of size and with a contrast of dividend distributing and non-distributing firms. This study will also serve them to conduct more studies on different factors on dividend policy, which may anticipate the aptitude and latency of capital markets, economic circumstances, and stock price volatility in the growing economy like Bangladesh.

\section{References}

[1] Glen Arnold, Corporate financial management, 4th edition (London, Financial Times Pitman Publishing, 2008).

[2] John Lintner, Distribution of incomes of corporations among dividends, retained earnings, and taxes, American Economic Review, 46(2), 1956, 97-113.

[3] Merton H. Miller, and Franco Modigliani, Dividend policy, growth and valuation of shares, The Journal of Business, 34(4), 1961, 411-433.

[4] Fischer Black, and Myron Scholes, The effects of dividend yield and dividend policy on common stock prices and returns, Journal of Financial Economics, 1(1), 1974, 1-22.

[5] Gong-meng Chen, Michael Firth, and Ning Daniel Gao, The information content of concurrently announced earnings, cash dividends, and stock dividends: an investigation of the Chinese stock market, Journal of International Financial Management and Accounting, 13(2), 2002, 101-124.

[6] J. J. Adefila, J. A. Oladipo, and J. O. Adeoti, The effect of dividend policy on the market price of shares in Nigeria: case study of fifteen quoted companies, International Journal of Accounting, 2(1), 2004, 1-10.

[7] Md. Hamid Uddin, and Golam Mohammed Chowdhury, Effects of dividend announcement on shareholders' value: evidence from Dhaka Stock Exchange, Journal of Business Research, 7, 2005, 61-72.

[8] David J. Denis, and Igor Osobov, Why do firms pay dividends? International evidence on the determinants of dividend policy, Journal of Financial Economics, 89(1), 2008, 62-82.

[9] W. A. Adesola, and A. E. Okwong, An empirical study of dividend policy of quoted companies in Nigeria, Global Journal of Social Sciences, 8(1), 2009, 85-101.

[10] M. J. Gorden, Optimal investment and financing policy, The Journal of Finance, 18(2), 1963, 264-272.

[11] Nickolaos Travlos, Lenos Trigeorgis, and Nikos Vafeas, Shareholder wealth effects of dividend policy changes in an emerging stock market: the case of Cyprus, Multinational Finance Journal, 5(2), 2001, 87-112.

[12] H. Kent Baker, Gary E. Powell, and E. Theodore Vei, Revisiting managerial perspectives on dividend policy, Journal of Economics and Finance, 26(3), 2002, 267-283.

[13] Melissa Myers, and Bacon Frank, The determinants of corporate dividend policy, Academy of Accounting and Financial Studies Journal, 8(3), 2004, 17-28.

[14] Ming Dong, Chris A. Robinson, and Chris Veld, Why individual investors want dividends, Journal of Corporate Finance, 1(12), 2005, 121-158.

[15] Dimitrios I. Maditinos, Zeljko Sevic, Nikolaos G. Theriou, and Alexandra V. Tsinani, Individual investors' perceptions towards dividends: the case of Greece, International Journal of Monetary Economics and Finance, 1(1), 2007, 18-31.

[16] Michael J. Barclay, and Clifford W. Smith, The maturity structure of corporate debt, The Journal of Finance, 1(2), 1995, 609-631.

[17] Dave E. Allen, and Veronica S. Rachim, Dividend policy and stock price volatility: Australian evidence, Applied Financial Economics, 6(2), 1996, 175-188.

[18] Jonathan Baskin, Dividend policy and the volatility of common stock, Journal of Portfolio Management, 3(15), 1989, 19-25.

[19] Horace Ho, Dividend policies in Australia and Japan, International Advances in Economics Research, 2(9), 2002, 91-100.

[20] Radhe Shyam Pradhan, Effects of dividends on common stock prices: the Nepalese evidence, Research in Nepalese Finance, 2003, $1-13$.

[21] Mohammed Nishat, and Chaudhary Mohammad Irfan, Dividend policy and stock price volatility in Pakistan, In Proceedings of 2003 11th Pacific Basin Finance, Economics and Accounting Conference, 2003.

[22] H. Kent Baker, Tarun Mukherjee, and Ohannes Paskelian, How Norwegian managers view dividend policy, Global Finance Journal, 17(1), 2006, 155-176. 
[23] Mohammed Amidu, How does dividend policy affect performance of the firm on Ghana Stock Exchange?, Investment Management and Financial Innovations, 4(2), 2007, 103-112.

[24] J. Raballe, and J. S. Hedensted, Dividend determinants in Denmark, Available at SSRN: https://ssrn.com/abstract=1123436, April $12,2008$.

[25] Muhammad Akbar, and Humayun Habib Baig, Reaction of stock prices to dividend announcements and market efficiency in Pakistan, The Lahore Journal of Economics, 15(1), 2010, 103-125.

[26] Khaled Hussainey, Chijoke Oscar Mgbame, and Aruoriwo M. Chijoke-Mgbame, Dividend policy and share price volatility: UK evidence, Journal of Risk Finance, 12(1), 2011, 57-68.

[27] H. Kent Baker, and Gary E. Powell, Dividend policy in Indonesia: survey evidence from executives, Journal of Asia Business Studies, 6(1), 2012, 79-92.

[28] Md. Abdullah al-Hasan, Md. Asaduzzaman, and Rashed al Karim, The effect of dividend policy on share price: an evaluative study, IOSR Journal of Economics and Finance, 1(4), 2013, 06-11.

[29] Abdullahil Mamun, Nazamul Hoque, and Abdullah Mohammad Ahshanul Mamun, Stock price reaction to dividend announcement: the case of Bangladesh capital market, Journal of Economics and Sustainable Development, 4(8), 2013.

[30] Michael Parkinson, The extreme value method for estimating the variance of the rate of return, The Journal of Business, 53(1), 1980, 61-65.

[31] Irene Kerubo Mogere, The relationship between dividend policy and stock return volatility of companies listed at the Nairobi Securities Exchange, University of Nairobi, Kenya, 2016.

[32] James C. Van Horne, John M Wachowicz, Gregory A Kuhlemeyer, Fundamentals of financial management, 12th edition (England, Pearson Education Limited, 2004).

[33] Kanwal Iqbal Khan, Muhammad Aamir, Arslan Qayyum, Adeel Nasir, and Maryam Iqbal Khan, Can dividend decisions affect the stock prices: a case of dividend paying companies of KSE, International Research Journal of Finance and Economics, 76, 2011, 67-74.

[34] Upananda Pani, Dividend policy and stock price behavior in Indian corporate sector: a panel data approach, Available at SSRN: http://ssrn.com/abstract=1216171, August 11, 2008.

[35] Hafeez Ahmed, and Attiya Y. Javid, Dynamics and determinants of dividend policy in Pakistan (Evidence from Karachi Stock Exchange non financial firms), International Journal of Finance and Economics, 25, 2009, 148-171.

[36] Shulian Liu, and Yanhong Hu, Empirical analysis of cash dividend payment in Chinese listed companies, Nature and Science, 3(1), 2005, 65-70.

[37] Dar-Hsin Chen, Hsiang-Hsi Liu, and Cheng-Ting Huang, The announcement effect of cash dividend changes on share prices: an empirical analysis of China, The Chinese Economy, 42(1), 2009, 62-85.

[38] Few Say Ling, Mohd Lukman Abdull Mutalip, Aidil Rizal Shahrin, and Mohd Said Othman, Dividend policy: evidence from public listed companies in Malaysia, International Review of Business Research Papers, 4(4), 2008, 208-222.

[39] Afzalur Rashid, A. Z. M. Anisur Rahman, Dividend Policy and Stock Price Volatility: Evidence from Bangladesh, Journal of Applied Business and Economics, 8(4), 2009, 71-81.

[40] Mian Sajid Nazir, Muhammad Musarat Nawaz, Waseem Anwar, and Farhan Ahmed, Determinants of stock price volatility in Karachi Stock Exchange: the mediating role of corporate dividend policy, International Research Journal of Finance and Economics, 55, 2010, 100-107. 